\title{
TRAINING MODEL BASIC ENGINEERING PASSING BALL
}

\author{
Siti Ayu Risma Putri ${ }^{1}$, Mutiara Fajar ${ }^{2}$, Endie Riyoko ${ }^{3}$, Ardo Okilanda ${ }^{4}$ \\ Universitas PGRI Palembang ${ }^{1,2,3}$, Universitas Negeri Padang ${ }^{4}$ \\ Sitiayurisma@gmail.com
}

\begin{abstract}
This research and development are structured to create the final result in the form of a product"Basic Technical Training Model for Volleyball Club, Volleyball Club, University of PGRI Palembang" which serves as a means for coaches as a reference in providing training sessions for athletes in their respective clubs. The method used in this research is Research and Development $(R \& D)$. The procedures or steps in the preparation of this research quote from the Borg and Gall research steps where there are 10 steps, but because the conditions in Indonesia are currently experiencing the Covid-19 pandemic, the researchers only used up to the third step of the research proposed. by Borg and Gall. The validity test of the volleyball passing practice model was carried out with 3 experts, namely coaching experts, volleyball experts, and media experts. The instrument used to collect data on the feasibility test of the basic technique of volleyball passing is a questionnaire or questionnaire with a rating scale. The evaluation data are in the form of descriptive qualitative and quantitative percentages. The results showed that the basic volleyball passing technique training model was feasible to be applied in the field to make it a reference for coaches. This is intended from several assessments carried out by coaching experts, volleyball experts and media experts. The final result of the assessment by the coaching expert showed that the basic volleyball passing technique exercise model was declared "feasible to apply" with a percentage of 92.9\%, the final result by the volleyball expert showed that the volleyball passing basic technique exercise model was declared "feasible to apply" with a percentage $85.71 \%$ of the final results of media experts showed that the product of the development book for the basic technique of volleyball passing was declared "feasible to apply" with a percentage of $80 \%$. So that it is feasible to be applied by coaches at their respective clubs as a reference for variations in training.
\end{abstract}

Keywords : Volleyball Basic Technique Training Model

Accepted: $24^{\text {th }}$ of January 2022

Correspondence Siti Ayu Risma Putri: Universitas PGRI Palembang, Indonesia. E-Mail: Sitiayurisma@gmail.com

DOI http://dx.doi.org/10.31851/hon.v5i1.6824

\section{(c) (i) (2)}

Jurnal Halaman Olahraga Nusantara licensed under a Creative Commons Attribution-ShareAlike 4.0 International License

\section{INTRODUCTION}

Sport as one of the physical activities of humans at this time is very influential on increasing the dignity of a nation, because sport is important to elevate the dignity of a nation, sport must be developed properly. This is stated in 
the Republic of Indonesia Law No. 3 of 2005 concerning the sports system, article 27 paragraph 1 which reads: "the guidance and development of sports achievements is carried out and directed to achieve sports achievements at the regional, national and international levels". Volleyball is a sport favored by Indonesian people, both men, women, young to adults. Opinion (Wa'asil et al., 2019) This game is a team sport played by six people per team and this game will run well if each player has at least mastered the basic techniques of playing volleyball).

"Volleyball is one of the truly global sports, played in sports halls and arenas (219 national federations are affiliated to the FIVB) and in parks, open spaces, and on beaches throughout the world" (Waite Pete, 2009) explains that volleyball is a truly global sport, played in sports halls and arenas (219 FIVBaffiliated national federations) and parks, open spaces and on beaches around the world. According to (Ahmadi, 2007) volleyball is a complex game that is not easy for everyone to do, because in volleyball it requires really reliable motion coordination to carry out all the movements in the volleyball game. "Volleyball is a very popular sport, and its development is full of constantly innovation and maturity of techniques and tactics" (Yiannis \& Panagiotis, 2005). Explains that Volleyball is a very popular sport, and its development is full of innovation and technical and tactical maturity. In addition (Valladares et al., 2016) defines Volleyball is considered a sport which is highly complex because of its technical, tactical and physical requirements.

Other separated by a net and each team consists of six people (Hasmara, 2017). A volleyball game is a complex game that is not easy for everyone to do (Rosdiani, 2012). It is said to be a complex game because in volleyball there are technical, physical, strategy, and tactical components. The technical component is a component that must be mastered by each team player. The basic technique of volleyball consists of various kinds of movements (Hidayat, 2015).

A team game, the pattern of cooperation between players is necessary to form a compact team, thus, mastery of basic techniques in volleyball individually 


\section{OLAHRAGA}

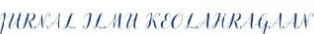

Jendral A. Yani Street Lorong Gotong Royong 9/10 U1 Palembang South Sumatera

email jurnal: jurnalhon@univpgri-palembang.ac.id situs web: http://www.univpgri-palembang.ac.id
Accredited

SINTA 3

is very important to master (Pasaribu, 2016). The series of attacks will be carried out properly and correctly if the mastery of the basic passing techniques of the players is very good and accurate because no matter how good the spikes are made by the attacker, it is impossible to run optimally if the passing is not accurate.

The basic technical mastery of the players, match statistics showed that the mistakes made by the team players as a whole were caused by errors in service (12.12\%) spike/smash (17.85\%), block errors (17.68\%), the top pass error (27.12\%) the bottom pass error (26.23\%), the data is by the points earned in each match, the facts found are in the form of errors that most occur in the basic technique of passing over and below is the basis for researchers in conducting development research.

In the match, it was seen that one of the causes of losing points made by the team understudy was not from a failed attack or an attack that was able to be returned by the opposing team, but more due to the mistakes of the team's players, many mistakes occurred in passing down and passing over both in series of attacks and when receiving an opponent's attack. Continuous and programmed training needs to be carried out to improve the Team's weaknesses in passing and passing in volleyball. The abilities of the players cannot be separated from the exercises carried out according to the training program provided by the team coach. Through coaching and training that is carried out systematically and continuously, it is expected to have the skills to play volleyball and be able to achieve high achievements (Primayanti, 2016)

Based on the above, to find out the model of basic volleyball passing technique training on the product to be developed by the researcher, a good and correct training model is needed. It is necessary to develop a model of upperpassing and lower-passing volleyball training at the University of PGRI Palembang for research products that will be developed further so that the research results obtained are feasible to be applied 
METHOD

This research is quantitative analysis research that is research using numbers. In this study, the author uses the Research and Development (R\&D) Borg and Gall (1998) method which can be translated into research and development in (Prof. Dr. Sugiyono, 2019a) research and development is a process/method used to validate and develop products. (Sugiyono, 2019, p. 297) states the research methods used to produce certain products, and test the effectiveness of these products. Meanwhile (Putra, 2015, p. 67) defines it as a research method that is intentional, systematic, aimed/directed to find, formulate, improve, develop, produce, test the effectiveness of products, models, methods/strategies/methods, services, procedures which are superior, new, effective, efficient, productive, and meaningful. Next (HAVIZ, 2016) explains simply about development research.

The explanations are (1) development research is a study of the process and specific effects of the impact of learning design and development, (2) development research is the use and implementation of products resulting from the design, development, and evaluation of learning activities and (3) development research is a study of the whole process. or part of the process of designing, developing, and evaluating learning. Sometimes, development research is also known as design research. In this development research, the product developed is a volleyball passing training model. This study, it is more focused on producing several models of volleyball passing exercises.

The steps in the Research and Development method are not standard things that must be followed, the steps taken can be adjusted to the needs of the researcher. The development procedure is the steps that must be followed before producing a product. However, according to (Kemala \& et al., 2020) confirmed data as of August 13, 2020, as many as 132,816 Covid cases in Indonesia were confirmed and 27,153 cases occurred in Palembang, 17,449 were declared cured and 959 died. The highest confirmed cases of Covid-19 occurred in the Palembang area compared to other regions in Indonesia, so people's activities 


\section{OLAHRAGA}

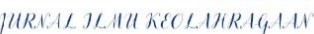

Jendral A. Yani Street Lorong Gotong Royong 9/10 U1 Palembang South Sumatera

email jurnal: jurnalhon@univpgri-palembang.ac.id situs web: http://www.univpgri-palembang.ac.id
Accredited

SINTA 3

outside the home need to be reduced. Most sports activities are carried out outdoors or in open spaces and require a wide scope, such as fields and buildings where people gather or gather. The closure of all sports facilities forced everyone to exercise at home with limited facilities and infrastructure. Sports activities at home are usually called TFH (Training From Home). With the Covid-19 pandemic condition, which did not allow researchers to meet face-to-face to conduct trials, therefore researchers only limited the steps to the stage of revision of the initial product draft. Here are the steps

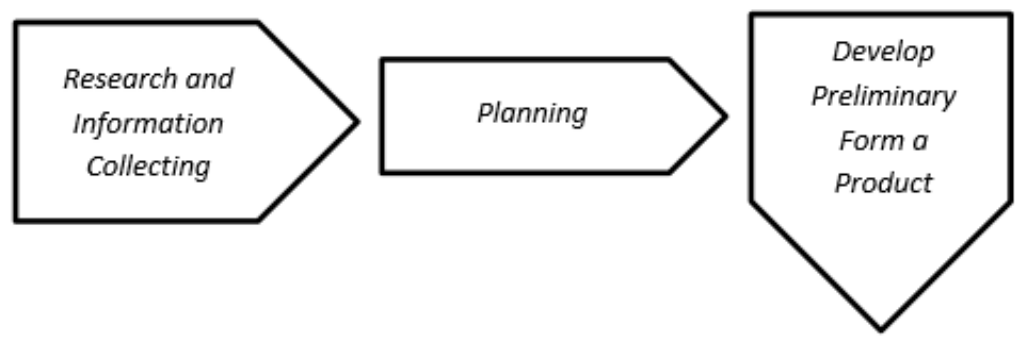

Figure 1. product the steps

The data collection in this study was by using interviews for needs analysis, expert evaluation questionnaires, model test questionnaires for athletes. The needs identification instrument in this study was prepared with the aim of obtaining data on the opinions of trainers on the model they have used or are currently using, and what kind of model they want. Once obtained, data analysis is then carried out. According to (Sukardi, 2011) functionally the usefulness of the research instrument is to obtain the necessary data when the researcher has stepped on the step of collecting information in the field. In this development research, the data collected is by using an instrument in the form of a product development feasibility questionnaire, namely; a) coaching experts, volleyball experts, and media experts. After the data was obtained, it was analyzed by coaching experts, volleyball experts and media experts using a Likert scale.

According to (Sugiyono, 2010) says that the Likert scale is used to measure attitudes, opinions and perceptions of a person or group of people about social phenomena. The answer to each instrument item using a Likert scale has a 
gradation from very positive to very.

The percentage is intended to determine the status of something that is presented and presented remains in the form of a percentage According to (Sugiyono, 2008. The formula used to process the data is as follows:

$$
\mathrm{P}=\frac{x}{X i} x 100 \%
$$

Description

$\mathrm{P} \quad$ : Yield Percentage

$\mathrm{X} \quad$ : Number Of Answer Score

$\mathrm{Xi} \quad$ : Number Of Answer Score

$100 \%$ : Konstanta

To make it easier to conclude the results of the analysis of the percentage of attractiveness and ease of product development, classification criteria are set.

Table 1. classification criteria

\begin{tabular}{|c|c|c|}
\hline Persentase & Categori & Description \\
\hline $80-100 \%$ & Very Good & Can be used without revision \\
\hline $61-80 \%$ & Good & Usable with minor revion \\
\hline $41-60 \%$ & Enough & $\begin{array}{l}\text { Not suitable for use, it is recommended not } \\
\text { use }\end{array}$ \\
\hline $21-40 \%$ & Not Good & Cannot be used \\
\hline $00-20 \%$ & Not Good & Cannot be used \\
\hline
\end{tabular}

After obtaining the percentage with this formula, then the feasibility of the volleyball passing practice model in this development research needs to combine the results of the validity test of each of these experts with the formula for the average assessment according to Suharsimi Arikunto (2014: 387) as follows:

Rating avarage $=\mathrm{X} 1+\mathrm{X} 2=\mathrm{X} 3: \mathrm{N}$

Description :

$\mathrm{X} 1=$ Result of data percetage value 1

$\mathrm{X} 2=$ Result of data percetage value 2

X3 = Result of data percetage value 3

$\mathrm{N} \quad=$ Total data

Furthermore, after getting the average expert assessment with the above formula, the results of this average assessment can be classified into four categories of eligibility using the following scale: 
Table 2. Scale

\begin{tabular}{lll}
\hline No & Score in presentage & Eligible Categori \\
\hline 1 & $<40 \%$ & Not Feasible \\
2 & $40 \%-55 \%$ & Not worth it \\
3 & $56 \%-75 \%$ & Quite dence \\
4 & $76 \%-100 \%$ & Woth it \\
\hline
\end{tabular}

(Arikunto, 2016)

The questionnaire used in this study is an assessment questionnaire with a score range of $(1)=$ Not Eligible, score $(2)=$ Less Eligible, score $(3)$ = Fairly Eligible, and score $(4)=$ Eligible

\section{RESULTS AND DISCUSSION}

Based on the data obtained from the validation instrument of coaching experts, including the suitability of the objectives of the training model variation, the implementation of the training model is clear and easy to understand by athletes, the suitability of the variation of the section with the overall passing technique, the material presented is simple and clear, is the variation of the training model simple and easy to understand? easy to imitate. The validation obtained gets a value of $92.9 \%$ of the maximum score. It can be stated that according to one of the coaching experts, at the validation stage "Basic Technique Training Model of Passing Volleyball Club at PGRI Palembang University by Ali Superman, M.Pd." obtained the category "Eligible to Apply.

Volleyball experts who have been carried out in the Basic Techniques of passing volleyball consisting of 14 Bottom Passing and 14 Upper Passing with a total of 28 variations, 24 feasible models, and 4 models that are declared inappropriate because they are not by volleyball training with an average value of $85,71 \%$, the validation obtained get a good/decent score, which is $85.71 \%$. It can be stated that according to one who is a volleyball expert, at the validation stage of the "Volleyball Passing Exercise Model by Dr. Waluyo, M.Pd" category "Eligible to be applied".

The validation obtained gets a good/decent score, which is $80 \%$ of the maximum score. It can be stated that according to one of the media experts, at the validation stage the "Basic Training Model of Passing Volleyball Club of the 


\section{OLAHRAGA}

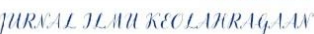

Jendral A. Yani Street Lorong Gotong Royong 9/10 U1 Palembang South Sumatera

email jurnal: jurnalhon@univpgri-palembang.ac.id situs web: http://www.univpgri-palembang.ac.id
Accredited

SINTA 3

$\overline{\text { University of PGRI Palembang by Sigit Purnomo, M.Pd., which was developed }}$ obtained the category of "Eligible to Apply".

The next step can be continued to find out the conclusion of the feasibility test of the volleyball passing training model in this development research, it is necessary to combine the results of the validity test of each of these experts with the formula for the average assessment of (Arikunto, 2014). The results of the average assessment of coaching validation experts, volleyball and media experts that the volleyball passing training model in this study got $86 \%$ further to determine whether this learning model is feasible or not feasible to apply then use the feasibility category of the percentage scale according to (Arikunto 2016)

\section{CONCLUSION}

The results of the research "Basic Technique Training Model of Passing Volleyball Club PGRI Palembang is categorized as good/feasible to be used as a variation of the training model in the process of training athletes. This can be seen from the results of the assessment of coaching experts, namely $92.9 \%$, volleyball experts $85.71 \%$, and media experts $80 \%$. So that if it is accumulated as a whole, it gets the feasibility results, which is $86 \%$.

\section{REFERENCES}

Achmad, I. Z. (2016). Hubungan Antara Power Tungkai, Koordinasi MataTangan, Dan Rasa Percaya Diri Dengan Hasil Keterampilan Open Spike Bola Voli. Jurnal Pendidikan Unsika, 4(1), 78-90.

Ahmadi, N. (2007). Panduan Olahraga Bolavoli. Era Pustaka Utama.

Ajayati, T. (2017). The Learning Model of Forearm Passing In Volleyball for Junior High School. JETL (Journal Of Education, Teaching and Learning), 2(2), 218. https://doi.org/10.26737/jetl.v2i2.289

Anandita. (2010). Mengenal Olahraga Vol. Kuadra.

Anwar, C. (2020). Journal of Sport Coaching and Physical Education Analisis Biomekanika Open Smash Bola Voli di Club Bina Taruna Semarang Abstrak. 5(1), 76-82.

Aprili, I. S., Supriatna, E., \& Triansyah, A. (n.d.). Abstact This research aims to develop new innovations in the form of volleyball block tools that can help optimize the volleyball block training process and help optimize the results 
of volleyball smash exercises. This research is a research and developm. $1-8$.

Arfa, M., Akhmad, I., \& Nugraha, T. (2020). Different Effects Between Cooperative and Sociometric Learning on Lower Passing Learning Outcomes in Volleyball Games of Grade VIII Students at SMP Negeri 14 Medan. 384(Aisteel), 475-478. https://doi.org/10.2991/aisteel$\underline{19.2019 .105}$

Arikunto, S. (2016). Prosedur Penelitian, Rineka Cipta, Jakarta. Tahun.

Prof. Dr. Sugiyono. (2019a). Metode Penelitian Dan Pengembangan Research And Development. Alfabeta.

Sugiyono. (2019). Metode Penelitian Kuantitatif, Kualitatif, dan R\&D. Alfabeta.

Trianto. (2007). Model Pembelajaran Terpadu dalam Teori dan Praktek. Pustaka Ilmu.

Valladares, N., García-Tormo, J. V., \& João, P. V. (2016). Analysis of variables affecting performance in senior female volleyball world championship 2014. International Journal of Performance Analysis in Sport, 16(1), 401411. https://doi.org/10.1080/24748668.2016.11868895

Viera, B. J. F. dan B. L. (2000). Volleyball Step to Succes Second. Human Kinetics.

Wa'asil, F., Hernawan, H., \& Humaid, H. (2019). Defense Exercise Model of Volleyball Fw for Beginner. Jurnal Pendidikan Olahraga, 7(2), 96. https://doi.org/10.31571/jpo.v7i2.1166

Waite Pete. (2009). Aggressive Volleyball. Human Kinetics.

Waluyo dan Sukirno. (2012). Cabang Olahraga Bola voli. Universitas Sriwijaya.

Widiastuti M. (2004). Model Pembelajaran dengan pendekatan Bermain pada mata kuliah pencak silat. Jurnal Ilmu Keolahragaan Fortius, Vol.4 No.(September 2004 ISSN 1411-8610. 118-131). 